\title{
Osmanlı Kapitülasyonlarının Tesisi: Zihniyet Bağlamında Bir Bakış
}

\author{
Cumali BOZPINAR*
}

ÖZ

Osmanlı kapitülasyonları ilk zamanlarda (Klasik Dönem'de) kendinden beklenen işlevleri yerine getirmiştir. Bununla birlikte zaman içinde yararlılıkları kaybolarak XIX. yüzyllda Osmanlı ekonomisi için bozucu etkiler doğurur olmușlardır. Osmanlı Devleti’nin yaklaşık altı yüz yıl gibi uzun bir dönem varlığını koruduğu dikkate alındığında, söz konusu kurumun kuruluşuna etki eden iktisadi saiklerin araştırılması önem arz etmektedir. Bu çalışma bir derleme türündendir. Ulaşılabilen ikincil kaynaklarla sınırlı olmak üzere, Osmanlı kapitülasyonlarının ortaya çıkışı iktisat tarihi perspektifinden ele alınmışır. Elde edilen temel sonuç, Osmanlı kapitülasyonlarının ortava çıkıșı hususunda Mehmet Genç’in ortava koyduğu Osmanlı iktisadi dünya görüsünün temel ilkelerinin geçerli olduğudur. İaşe ilkesi doğrultusunda "Osmanlı ülkesi içinde malların mümkün olduğu kadar bol, kaliteli ve ucuz olmasının sağlanması yoluyla” halkın refahı arttırlmıștır. Fiskalizm ilkesi çerçevesinde, dıș ticaret devlet için önemli bir gelir kaynağı olmuştur. Gelenekçilik ilkesine uygun bir şekilde, Osmanlı Devleti'nin ortaya çıkışından önce tesis edilmiş dış ticaret düzeni, kurulu düzeni bozmamak adına tanınmıștır. Son olarak, Osmanlı kapitülasyonlarının tesisinin Weberyan subjektif rasyonaliteye dayandırıldığı kabul edilebilir.

Anahtar Kelimeler: Osmanll, kapitülasyon, Mehmet Genç, zihniyet.

\section{The Establishment of the Ottoman Capitulations: A Perspective in the Context of Mindset}

\begin{abstract}
Initially, the Ottoman capitulations were implemented as expected. However, their utility gradually diminished, and they became disruptive to the Ottoman economy in the XIXth century. The Ottoman state endured for approximately six hundred years; therefore, it is important to investigate its economic motives. This is a compilatory study. The establishment of the Ottoman capitulations has been handled from the perspective of economic history, limited to available secondary sources. The findings obtained in the study support Mehmet Genç's theory of Ottoman economic thought. In line with the principle of provisionism, the welfare of the people was improved "by ensuring that the commodities were as plentiful, of high quality and cheap as possible." Within the framework of fiscalism, foreign trade was an important source of income for the state. In accordance with traditionalism, the foreign trade arrangement preceding the Ottoman state was recognized to avoid disruption of the established order. Finally, the establishment of Ottoman capitulations was based on Weberian subjective rationality.

Keywords: Ottoman, capitulation, Mehmet Genç, mindset.
\end{abstract}

\section{Giriş}

Ticari ve hukuki imtiyaz ve sözleșmeler niteliğindeki kapitülasyonlar, Osmanlı Devleti’nin sadece büyük devlet olmak amacıyla kullandığ araçlardan birisi olmaktan çok, muhtelif beklentilerin karşılanması amacıyla kullanılmıştır. Bu araç sayesinde esas olarak "yabanc1 tüccarın gidip gelmesiyle Osmanlı topraklarında ticari ve iktisadi hayatın gelişip canlılık kazanması" amaçlanmıştır (Kütükoğlu, 1999, s. 330). İlk zamanlarda devletin güçlü siyasi, iktisadi ve askeri yapısı nedeniyle kapitülasyonlar kendinden beklenen işlevleri yerine getirmiştir. Bununla birlikte ilerleyen dönemlerde Osmanlı Devleti lehine değil ayrıcalık elde etmiş devletler lehine işlev görmeye başlamıştır. Nihayet XIX. yüzyılda, devletin zararına işleyen bir hale gelmiş ve devlet adamlarının girişimlerine rağmen taraf devletlerin baskıları nedeniyle ancak 24 Temmuz 1923 ’te Lozan Anlaşması ile yürürlükten kaldırılabilmiştir (Acartürk ve Kılıç, 2011, s. 2).

$\mathrm{Bu}$ çalışma bir derleme niteliğinde olup ulaşılabilen kaynaklarla ${ }^{1}$ sınırlı olmak üzere Osmanlı kapitülasyonlarının ortaya çıkışı iktisat tarihi perspektifinden ele alınmıştır. Konunun böylesine dar bir çerçevede tutulmasının sebebi; yaklaşık altı yüz yıl bir imparatorluk niteliğiyle tarih sahnesinde kendini

\footnotetext{
*Dr., Çevre ve Şehircilik Bakanlığı (Millî Emlak Genel Müdürlüğü), cumalispontik@gmail.com Makalenin Gönderim Tarihi: 11.04.2021; Makalenin Kabul Tarihi: 02.08.2021
} 
göstermiş bir devletin, nihayetinde çöküşüne yol açan önemli bir kurumu tesisinde belli bir iktisadi rasyonellik bulunup bulanmadığına dair bilimsel merak olarak ifade edilebilir.

\section{Kapitülasyon Kavramı ve Tarihsel Kökeni \\ 2.1. Kapitülasyon Kavramı}

Kapitülasyon kelimesinin kökeninin "anlaşmaların bölündüğü fasılları belirten" Latince "capitula" kelimesi olduğu belirtilmektedir. Dolayısıyla kapitülasyon ilk olarak "fasıl" anlamında kullanılmıştır. Sonrasında "boyun eğme" anlamında kullanır olmuştur (Kuran, 2018, s. 272-3).

Kapitülasyonun muhtelif tanımlarından biri, savaş zamanında yapılan bir anlaşma olup bununla bir silahlı güç, şehir ya da bölge silahlı düşman kuvvetlerine teslim edilmektedir. Başka bir anlamı ise yemindir. Osmanlı Devleti özelinde ise kapitülasyon "bir yabancıya başka bir ülkede kendi ülkesi yasalarını uygulayabilme hakkı veren yurtdışı ilişskilere ilişkin bir anlaşma" olarak tanımlanmıştır (Sousa, 1933, s. 1).

Köprülü (1931) ise şöyle tanımlamıştır: "Avrupalı devletlerin kendi ülkeleri dışındaki sürekli ya da geçici olarak bulunan yurttaşlarının, ülkesinde bulundukları devletin yetkilerinin dışında kalmak ve kendi devletlerinin yetkisine bağımlı olmak biçiminde elde ettikleri ayrıcalıklar ile ticaret ve gümrük konularında elde ettikleri kolaylıklar ve imtiyazlar.” (aktaran Acartürk ve Kilıç, 2011, s. 3).

Türk Dil Kurumu Güncel Türkçe Sözlügünde ise kapitülasyon "Bir ülkede yurttaşların zararına olarak yabancılara verilen ayrıcalık haklanı" olarak tanımlanmış̦tır (Kapitülasyon, t.y.).

Bu çalışmada, Sousa'nın (1933) kabul ettiği gibi kapitülasyon, bir yabancıya başka bir ülkede kendi ülkesi yasalarını uygulayabilme hakkı veren yurtdışı ilişkilere ilişkin bir anlaşma anlamında kullanılmışır.

\subsection{Kapitülasyonun Tarihsel Kökeni}

Kapitülasyon kavramının ilk kez resmi olarak bir anlaşmada kullanımı 1275 yllına tarihlendirilmekte olup bu tarihte Yunan İmparatoru'nun Cenevizliler'e ilişkin bir deklarasyonunda bu kavram kullanılmıştır (Sousa, 1933, s. 2).

Osmanlı Devleti'nde yabancıların sınır ötesi haklar elde etmesi anlamında kapitülasyonlar, günümüzde olduğu gibi ülkelerin birbiriyle yaptıkları ticari anlaşmalar ve imtiyazlardır. Buna göre Osmanlı hukuk sistemi yabancılara resmi olarak re'sen bir hak koruması sağlamadığından gayrimüslimlere -Osmanlı toprağında ikamet etmeleri halinde- kendi yarg1 yetkilerine devam etmeleri izni verilmiştir ki böylece Osmanlı kapitülasyonları ortaya çıkmıştır. Burada Sousa (1933, s. 15)'nın ileri sürdüğü "kapitülasyonların Müslüman ve gayrimüslimler arasındaki dinsel ve sosyal farklardan kaynaklı olarak ortaya çıktı̆̆ı" görüşünün, kapitülasyonların ticari anlaşmalar ve imtiyazlar niteliğinde olduğu dikkate alındığında sorunlu olduğu kabul edilebilir. Başka bir deyişle kapitülasyonların oluşumunu taraflar arasındaki dini ve sosyal farklara bağlamak uygun değildir. Nitekim tarihsel olarak bakıldığında Hristiyan ülkeler arasında da kapitülasyonlar verildiği bilinmektedir².

Bizans İmparatorluğu’nda da kapitülasyonların olduğu görülmektedir. Öyle ki Venedikliler, Cenevizliler ve diğer devlet uyrukları Bizans ülkesinde bağımsız ulusal yargılama sistemine sahip olmuşlardır (Sousa, 1933, s. 17).

Sonuç olarak Osmanlı kapitülasyonlarının kökeninin Osmanlı öncesi döneme dayandığı söylenilebilir.

\footnotetext{
2 Bizans İmparatorluğu ile Venedik şehir devleti arasında 1082'de imzalanan anlaşmayla Venedik tacirleri Bizans ülkesinde neredeyse sınırsız nitelikte ticari imtiyazlar elde etmişlerdir. Buna göre Venedik tacirleri bundan böyle ülkenin her yerinde devlet görevlilerinin müdahalesi olmaksızın ticaret yapabilir hale gelmişlerdir. Öyle ki Bizans memurları Venedikliler'in ticari mallarını kontrol etme ve ticari faaliyetlerini vergilendirme hususlarında yetkisiz kılınmışlardır. Böylece 1082 yılında yapılan anlaşma sayesinde Venedikliler Bizans ülkesindeki tüm liman ve şehirlerde elde ettikleri "vergiden muaf her türlü ticaret serbestliği" imtiyazı ile yerli tacirlerden fazlasıyla üstün hale gelmişlerdir. Ayrıca kendilerine İstanbul'da birkaç imalathane ile Galata'da üç iskele de verilmiştir. Görüldüğü üzere 1082 yllında yapılan anlaşma Bizans ülkesinin tüm geleceğini ipotek altına koymuş ve Bizans-Batı ilișkilerinde ilkinin aleyhine bir dönüm noktası niteliğinde olmuștur. Sonraki yıllarda benzeri ayrıcalıklar Cenova ve Pisa gibi diğer İtalyan şehir devletlerine de tanınmış ve zamanla imtiyazların kapsamı genişletilmiştir. Buna bağlı olarak Bizans İmparatorluğu Batılı ülkeler karşısında ekonomik bağımsızlı̆ını kaybettiği gibi her bakımdan Batılı ülkelere bağlı bir uydu yönetim haline gelmiştir. Bununla birlikte söz konusu imtiyazların verildiği dönemde Bizans yönetimi gücünü kısmen de olsa hâlâ koruduğu için başlarda bu durumdan fazla etkilenmemiştir fakat yıllar geçtikçe ekonomisini çökerten Batıllı ülkelerin baskısına daha fazla maruz kalmıs ve bu süreçten kurtulamamışır (Demirkent, 2000, s. 139-41).
} 
Diğer taraftan Osmanlı Devleti’nde yabancıların hukuki durumlarının belirlenmesinde gayrimüslimlerin "harbi" olarak adlandırılmalarının pratikte hiçbir önemi bulunmamışır³. Kapitülasyonların kökeni İslami devletlere atfedilmediği gibi İslam hukukunda yerleşik yabancılar düşman olarak görülmemiştir (Sousa, 1933, s. 42).

\section{Osmanlı Devleti'nde Kapitülasyonlar}

\subsection{Kapitülasyonların Doğuşu}

İstanbul'un fethiyle Osmanlı idaresi altna geniş bir gayrimüslim nüfus girmiştir. Osmanlı Devleti oldukça kısa bir sürede hâkimiyetini Avrupa, Asya ve Afrika'da genişletmesine bağlı olarak zamanın Avrupa ile doğu ülkeleri arasındaki en önemli ulaslararası ticaret yollarının kontrolünü de ele geçirmiştir. Dahası Osmanlı yöneticileri, ülkede yabancıların ticaret yapmaları hususunda gerekli kolaylığı göstermişler ve sonuçta ülke içinde yabancı unsurların sayısı artmıştır ${ }^{4}$ (Sousa, 1933, s. 43-4).

Burada belirtmekte fayda vardır ki Türkler uzun zaman önce İslam toplumlarılya etkileşim içine girmişler ve o zaman daha yüksek bir medeniyet düzeyinde oldukları için onlardan etkilenmişlerdir. Bu bağlamda Osmanlı Devleti'nin diplomatik haklar dâhil yabancılara ticaret ve iş kurma özgürlüğ̈ garantisi ve Hristiyan yargıçların korunmasını İslam devletlerinden örnek aldığı da ileri sürülmektedir ${ }^{5}$ (Sousa, 1933, s. 44-5). Nitekim II. Mehmed, İstanbul'un fethini müteakip şehirde var olan başta Rumlar olmak üzere gayrimüslimlere zimmî́ statüsü tanıyarak onları yerlerinde bırakmıştır (Sousa, 1933, s. 48-9). Aynı şekilde Ermeniler'den 200 aileyi İstanbul'a getirtmiş ve Yahudi cemaatini tanımıştır. Bunlanın yanında Ekümenlik Piskoposu'nun imtiyazlarını tanımış ve ona yargısal güç de vermiştir. Diğer taraftan fetihten birkaç gün sonra İstanbul'daki Cenevizliler'e de ayrıcalıklar tanınmıştır (Sousa, 1933, s. 50-1).

Osmanlı kapitülasyonları denilince, XVI. yüzyıl öncesinde örnekleri bulunmasına karşın7, genellikle ilk olarak akla 1535 yllinda Fransa'ya verilen ve daha sonra yedi kez yenilendikten sonra süresiz hale getirilen ayrıcalıklar gelmektedir. Bu kapitülasyonlar sonraki dönemde verilen kapitülasyonlara bir temel teşkil etmiştir (Sousa, 1933, s. 54-9).

Osmanlı Devleti'nde bazı nedenlere bağlı olarak kapitülasyonların ortaya çıktı̆̆ kabul edilebilir.

İlk olarak Osmanlı öncesi dönemde kapitülasyonların varlığı belirtilebilir. Osmanlı Devleti XIII. yüzyıl sonlarında kurulduğunda, çevresinde kapitülasyon kurumu yaşar durumdadır. Şöyle ki Bizans İmparatorluğu iç ve dış siyasetini sürdürmek için çeşitli ülkelere belli imtiyazlar tanımıştır. Benzeri uygulamalara Selçuklu yönetimleri de başvurmuştur. Dolayısıyla Bizans ve Selçuklu bölgelerini egemenliği altına almasının ardından kapitülasyon kurumu da Osmanlı Devleti'nin kurumlanı arasına dâhil edilmiştir (Acartürk ve Kılıç, 2011, s. 3). Esasında burada -ayrıntıları aşağıda anlatılacak olan- Osmanlı zihniyet ilkelerinden gelenekçiliğin bir uygulamasından bahsetmek mümkündür. Osmanlı yöneticilerinin rehber ilkelerinden biri olan bu ilke, kurulu düzenin devam ettirilmesi anlamiyla kapitülasyon kurumunun sahiplenilmesine yol açmıştır.

\footnotetext{
${ }^{3}$ Dönemin uluslararası alanda genel ilişki biçiminin savaş olmasına bağlı olarak Osmanlı yöneticilerinin gözünde yabancılar fiili veya olası düşman olarak görülmelerinden dolayı kendilerine "düşman" karşıllğı olarak "harbi" veya "ehl-i harp" denilmiştir. Ayrintılar için bk. Özel (1997).

${ }^{4}$ Osmanlı toplumunda ticaret yüceltilen bir iktisadi faaliyet alanı olmuştur. Bu kapsamda devlet tarafindan tüccarın desteklendiği ve devletin bizatihi ticari hayata dahlinin olduğu söylenebilir. Bu durumun kanıtları olarak iç ticaretin gelişmesi için kurulan pazarlar, panayırlar, çarşı ve hanlar ile esnaf/zanaat loncaları sayılabilir. Diğer taraftan Osmanlı dış ticaretinin aktörleri arasında Osmanlı tebaasından gayrimüslimler olduğu gibi Müslüman tebaadan kimseler de yer almıştır. Başka deyişle Osmanlı ülkesi yabancı tüccar için cazip olmakla birlikte Osmanlı tüccarı da dış pazarlarda ticaretle iştigal etmişlerdir. Dahası, ülkede kıtllğı çekilen veya kamusal hizmetlerde kullanılmak üzere ihtiyaç duyulan malların tedariki için Rusya, Lehistan, Venedik ve İngiltere gibi ülkelere zaman zaman "Hassa tacir" diye bilinen satınalma heyetleri gönderilmiştir. Bunun yanında Venedik'te Osmanlı tebaasından tacirlerin ticari faaliyette bulundukları, Venedik'e sık sık gidip geldikleri ve iki ülke arasındaki 1573-1645 barış döneminde 1575 'de Venedik yönetimi tarafindan yaptırılan üç yüz kişi kapasiteli "Fontico de Turchi" denilen misafirhanede konakladıkları belirtilmektedir (Tabakoğlu, 1998, s. 249; Valensi, 2015, s. 161-2).

${ }^{5}$ Konunun milliyet temeline indirgenmemesi gerekmektedir. Şöyle ki İslam hukukunun meşru gördüğü ve İslam devletlerinde geçerli bir uygulamayı Osmanlı sultanlarının da kendi ülke ve tebaası için uygun görerek yürürlüğe koymasında bir beis yoktur. Burada Sausa (1933)'nın üzerinde durduğu konu esas olarak müste'min hukukuna girmektedir.

6 no.lu dipnota bakınız.

7 İlk Osmanlı kapitülasyonları, Rumeli’ye geçişle birlikte 1352 yılında Cenevizliler’e verilmiştir (İnalcık, 2009b, s. 316).
} 
İkinci olarak İslam fikhında "amân" kurumunun mevcudiyeti belirtilebilir. Osmanlı Devleti tarafindan, "dostluk ve samimi iyi niyet" sözü veren gayrimüslimlere ülke sınırları içinde ikamet, seyahat ve ticaret için gerekli güvenlik garantisi (amân) verilmiştir (İnalcık, 2009a, s. 237; Kuran, 2018, s. 289-90)8. Dolayısiyla Osmanlı Devleti'nde kapitülasyonlar, amân kurumuna uygun olarak benimsenmiştir.

Üçüncü olarak Avrupa ülkeleriyle siyasi dostluk kazanma amacı belirtilebilir. Osmanlı zihniyetinde kapitülasyon verilmesi Hristiyan dünyası içinde müttefik kazanılması anlamına gelmiştir. Böylesi bir müttefik kazanımı, birlik halindeki Hristiyan dünyasını da zayıflatmıştır. Bu kapsamda Venedik, zaman zaman verilen ticari ayrıcalıklarla tarafsızlaştırlmış ve güçlü donanmasını "Haçlı zihniyetindeki Papa'nın emrine vermesi" önlenebilmiştir (İnalcık, 2009a, s. 238)9.

Son olarak iktisadi nedenler belirtilebilir. Bu kapsamda Osmanlı Devleti kapitülasyon verilmesi sayesinde kalay, kurşun, çelik, barut ve benzeri kimyasal maddeleri, özellikle altın ve gümüş sikkeler gibi k1tlğı çekilen malları veya üst tabakanın kullandığ yünlü, mücevher, kristalden yapılma eşya, ayna ve saat gibi lüks malları Avrupa ülkelerinden elde edebilmiştir. Yine artan ticaret sayesinde önemli miktarda gelir elde edilmiştir. Bu gelirler arasında esas olarak gümrük vergileri ve harçlar öne çıkmaktadır (İnalcık, 2009a, s. 238; Kuran, 2018, s. 322). Söz konusu gelirlerin arttırılabilmesinde ülkenin coğrafi olarak dünyanın belli başlı ticaret yolları güzergâhı -İpek Yolu ve Baharat Yolu- üzerinde yer almasından yararlanılmışttr. Öyle ki Osmanlı ülkesinden geçen Baharat Yolu güzergâhının Ümit Burnu'nun keşfiyle değişmesinin önüne geçebilmek için Osmanlı yönetimi tarafindan kapitülasyonların bir araç olarak kullanıldığ1 ileri sürülmektedir (Acartürk ve Kılıç, 2011, s. 4). Bununla birlikte Kuran (2018)'a göre bu değerlendirme k1smen kabul edilebilir:

“...Rakip ticaret yolları elbette Orta Doğu hükümdarlarının stratejilerini etkiledi. Ne var ki, bu durum Vasco Da Gama'nın Hint Okyanusu'na ulaşmasından epey önce var olan kapitülasyonlar açısından kilit rol oynamış olamaz. Daha kritik bir nokta, eski ticaret yollarını desteklemek için yabancılar lehinde bir ayrımcilı̆ga gerek bulunmamaktaydı. Transit ticaret, inanç ve milliyet farkı gözetmeyen ticari teşviklerle canlandırılabilirdi." (Kuran, 2018, s. 278).

Gerçekten de Ümit Burnu üzerinden Hindistan ticaret yolunun açılmasından çok önce Osmanlı Devleti batılı ülkelerle ticaret anlaşmaları yapmış ve onlara muhtelif imtiyazlar vermiştir. Bu kapsamda şunlar belirtilebilir: Osmanlı Devleti tarafindan ilk kapitülasyon 1352'de Rumeli'ye ilk geçildiği sırada Venedik şehir devleti ile savaş halinde olan ve dostane ilişkiler içinde bulunulan Cenova şehir devletine verilmiştir. Venedik konsoloslukları XIV. yüzyıl ortalarında Ayasuluk (Selçuk) ve Balat’ta tesis edilmiş durumdadır. I. Bayezid zamanında bu yerler Osmanlı yönetimine geçince söz konusu imtiyazlar onaylanmış ve ülkenin tamamına teşmil edilmiştir. II. Mehmed döneminde 1479'da yapılan bir anlaşma ve bunun II. Bayezid döneminde 1481'de yenilenmesiyle Venedik şehir devleti daha önceki imtiyazların yanında Karadeniz'de Kefe ve Trabzon'da ticaret yapma imtiyazını almıştır (İnalcık, 2000).

\footnotetext{
${ }^{8}$ Osmanlı hukuk sisteminde bugünkü anlamda devletler hukuku diye ayrı bir hukuk dalına yer verilmemiştir. Osmanlı Devleti’nde İslam hukuku kapsamında ülkeye darülislam, diğer ülkelere darülharp denilmiştir. Darülislam, Müslümanların hâkim olduğu ve İslam hukukunun uygulandığı ülkedir. Halkın çoğunluğunun Müslüman olması şart değildir. Darülharp ise, Müslümanların egemenliğinde bulunmayan ve İslam hukukunun uygulanmadığı ülkedir. Yabancı ülkelere bu adı vermelerinin esas sebebi, dönemin uluslararası alanda genel ilișki biçiminin savaș olmasıdır. Fiili veya olası düșman konumundan dolayı darülharp denilen yabancı ülkelerin tebaasına "düşman" karşllı̆̆ olarak "harbi" veya "ehl-i harp" denilmiştir. Darülharp tebaasından bir İslam ülkesine amânla belli bir süre için girenlere "müste’men" denilmiştir. Bununla birlikte aldıkları amânla can ve mal güvenliğine sahip olmaları bu kimseleri harbi olmaktan çıkarmamıştr. Osmanlı Devleti’nde İslam hukuku kapsamında zimmet akdi uygulanmış olup zimmîler, devlete hukuki ve aynı zamanda siyası bir bağla bağlı kabul edilmişlerdir. Osmanlı Devleti'nin kuruluşundan itibaren gayrimüslim tebaa İslami zimmet ve amân kurumları çerçevesinde yönetilmiştir. "Bir kimsenin yüklendiği, ödemeye mecbur olduğu borç; himaye; anlaşma" anlamlarına gelen zimmet kökünden türeyen zimmî "kendisine güvence verilen, himaye altına alınan kişi” demektir. Zimmîler, zimmet anlaşmasına dayanarak İslam ülkesinde vatandaş olarak yaşamışlar ve devlete cizye ödemelerine karşılık güvence (zimmet) elde etmişlerdir. Böylece Osmanlı ülkesinde yaşayan gayrimüslim tebaanın üç ana kategoride değerlendirildiği söylenebilir: Zimmî, müste'men yani amân verilenler ve harbi. Her üç grup için ayrı hukuki düzenlemeler çerçevesinde hukuki koruma mevcut olmuştur. Ayrıntılar için bł. Özel (1984), Özel (1997, s. 112-4), Akgündüz (2011, s. 983-92), Fayda (2013), Kenanoğlu (2013), Akgündüz (2018, s. 800, 1370) ve Yaman (2013).

9 II. Mehmet Dönemi'nde (1451-1481) Venedik'in muhtemel saldırılarının önlenmesi amacıyla Venedikliler'in İstanbul'da ikamet etmelerine izin verildiği ve Venedikli tüccara $\% 2$ gibi düşük bir gümrük vergisi ödemeleri kaydıyla ticaret yapabilme hakkının tanındı ̆̆ bilinmektedir (Pamir, 2002, s. 84).
} 


\subsection{Osmanlı İktisadi Dünya Görüşü Çerçevesinde Kapitülasyonlar}

Osmanlı iktisadi dünya görüşünün temel ilkelerinden kaynaklı olarak Osmanlı toplumunda ticarete ve dolayısıyla tüccara önem verilmiştir. Bunlardan iaşe (provizyonizm) ilkesi kısaca "ülke içinde mal arzının mümkün olduğu kadar bol, kaliteli ve ucuz olmasını sağlamak yoluyla" halkın refahının artırılması amacı güdülmesidir. Bu doğrultuda Osmanlı Devleti, dönemin Avrupa ülkelerinin merkantilist politikalarından farklı olarak, ticareti bir amaç olarak değil, bir araç olarak görmüştür. Dahası devlet, elindeki imkânları kullanarak ticareti desteklemiştir. Fiskalizm olarak adlandırılan ikinci ilke ise "devlete ait nakdi gelirleri mümkün olduğu kadar yüksek düzeye çıkarmak ve ulaştığı düzeyin altına düşmesini engellemek" amacının güdülmesi olarak ifade edilmiştir. Bu çerçevede ticaret devlet için önemli bir gelir kaynağı olmuştur (Genç, 2012, s. 208). Gelenekçilik olarak adlandırılan son ilke ise "toplumsal ilişkilerde mevcut dengeleri ve eğilimleri olabildiğince korumak ve bunlarda bozulma/sapma yönündeki eğilimlerin önüne geçmek ve değişme karşısında bunları ortadan kaldırıp yeniden dengeye dönmek bilincine sahip olunması"dır (Genç, 2012, s. 64) ${ }^{10}$. Nitekim hukukun kaynağı olarak şeriatın ve yetkili dini otorite tarafindan şeriata uygunluğu kabul ve tasdik edilen kanun ve örflerin vücut verdiği bütün düzenlemelerde bu ilke gözetilmiştir. Bunun yanında şeriatın açı şekilde kapsamına almadığı konularda bazı kurallar geçerli olmuştur. Padişahların çıkardığı kanunname denilen kurallar bunların başında gelmiştir. Bundan başka mahalli örf ve adetlerden kaynaklanan düzenlemeler de mevcut olmuştur. Kanunnamelerle örf ve adetler şeriatın dışında olmakla beraber ona aykırı olmamak şart ile yürürlüğe girmiş olduğu için uyulması zorunlu olan kurallar olmuştur (Genç, 2012, s. 65-6). Bu durumda daha önce belirttiğimiz Osmanlı Devleti tarafindan tanınan "amân" kurumunun bir çeşit padişah tasarrufu olan kapitülasyonlara şeriata uygunluk anlamında meşruiyet sağladığı ve dolayısıyla gelenekçilik ilkesiyle ilişkili olduğu söylenebilir. Diğer taraftan Küçükömer (2012, s. 42-3) diğer iki ilkeyi ifade eden kavramları (iaşe ve fiskalizm) kullanmaksızın, bu ilkelerin gereği olarak ithalatın teşvik edildiğini ve dolayısıyla Osmanlı Devleti'nde kapitülasyonlar verilmesinin bir lütuf değil zorunluluktan kaynaklandığı belirtilip bu hakları tanıyan "fermanların debdebeli, gösterişli ifadelerine aldanmamalıdır" şeklinde bir değerlendirmede bulunmuştur. $\mathrm{Bu}$ değerlendirmenin abartılı olduğu düşünülmektedir. Şöyle ki döneminin diğer devletleri gibi Osmanlı Devleti de birçok devletle siyasi ve ticari nitelikte anlaşmalar imzalayarak imtiyazlar vermiştir. Bu ilişkileri, devletin öncelikleri belirlemiş olup bu çerçevede yapılan anlaşmalar bazen lütuf, bazen de zorunluluktan kaynaklı olarak ortaya çıkmıştır. Dolayısıyla Osmanlı Devleti’nin diğer devletlerle yaptığı ve yabancılara imtiyaz sağlayan anlaşmalar "zorunluluk" gibi tek kalıba konulmamalıdır.

Avrupa ile ticari ilişkilerin analizi noktasında, Osmanlı Devleti'nin tarih sahnesine çıktı̆̆ dönemde 1300 dolaylarnnda- Avrupa ülkeleri kendi imalatı olan dokuma, kâğıt, cam, sabun vb. ürünlerini Doğu pazarlarında satup karşılığında pamuk, ipek, deri $v b$. ham maddeleri alır durumda olduğu belirtilebilir. Dahası bu ticarette aracılar artan ölçüde Avrupalı tüccarlar ve gemi sahipleri olmuştur. Osmanlı Devleti'nin ortaya çıktığı dönemde söz konusu gelişmeler olgunlaşmış durumdadırlar. Başka deyişle "Osmanlı Devleti, tabir caizse, bloklar arası oluşmuş, yerleşmiş bulunan uzun vadeli bu trendin içinde doğmuş, büyümüş ve zirveye turmanmıştur” (Genç, 2012, s. 209).

Yukanda ifade edildiği gibi Osmanlı Devleti'nin tarih sahnesine çıtığı dönemde Avrupa ülkeleri ile Doğu ülkeleri arasında iktisadi yapı bakımından mutlak bir farklılaşma nitelemesi için henüz erken olmakla birlikte ilerleyen süreçte aralarındaki ticaret yavaş yavaş ilkinin imalat ürünleri vermesi karşıllı̆̆ında ikincisinin ham madde vermesi şeklinde bir eğilime girecektir. Osmanlı yöneticilerinin, kuruluş dönemi ve sonrasında uluslararası ticaretteki mevcut işleyişi değiştirmeyi iktisadi zihniyet ilkeleri çerçevesinde uygun bulmadığ1 söylenebilir. Bu kapsamda kendilerinden önce verilmiş kapitülasyonlar tanındığı gibi bunlara yenilerinin eklenmesine devam edilmiştir.

Osmanlı Devleti'nde kapitülasyonlar 1517'ye kadar sadece İtalyanlar'a verilirken bu tarihten sonra diğer Avrupa devletlerine de verilmeye başlanmıştır (İnalcık, 2009a, s. 243). Osmanlı yöneticilerini böyle bir uygulamaya iten güdünün iktisadi faaliyetlerde referans çerçevesi oluşturan zihniyet ilkeleri olduğu kabul edilebilir. Şöyle ki ithalatı serbest bırakmak ve kriz dönemlerinde darlığı çekilen ham madde ve mallar için ihracat yasakları koymak suretiyle bir taraftan ülke içi mal ve ham madde arzının azamileştirilmesi, diğer

\footnotetext{
${ }^{10}$ Bu üç ilkeye dayalı olarak Osmanlı iktisadi zihniyeti C. Bozpinar tarafından Osmanlı rasyonalitesi olarak adlandırllıp Weberyan anlamda subjektif rasyonellik içinde değerlendirilmiştir. Ayrıntılar için bk. Bozpinar (2018) ve Bozpinar (2020).
} 
taraftan da uluslararası ticaret kanalıyla gümrük vergileri elde edilmesi amaçlanmıştur. Dönemin Avrupa ülkeleri ise Osmanlı Devleti'nin uygulamalarının tersi denilebilecek şekilde merkantilist politikalar uygulamışlardır. Şöyle ki değerli madenleri (altın ve gümüşü) başlıca ekonomik kaynak olarak görüp zenginliği bunların miktarının büyüklügüyle ölçmüşler ve bu kapsamda ihracatlarını artırarak ithalatlarını kısıtlamışardır. Tarafları yönlendiren zihniyet farklı olsa da amaçları birbirini tamamlayıcı nitelikte olmuştur. Burada İnalcık'tan (2009b, s. 405) aktarma yapmak uygun olacakttr:

“...Merkantilist düşünceye yabancı kalan Osmanlı devlet adamlan, ülkede mal bolluğu sağlamaya ve ticari vergilerden alınan devlet gelirlerinin azalmamasına dikkat ederlerdi. ...kapitülasyonlar, gereksinim duyulan bazı önemli maddelerin (başlıca ince yünlü kumaş, kalay, çelik, barut ve kristal, saat gibi lüks eşya) sağlanması ve hazineye ait gümrük gelirinin artması göz önünde tutularak kaygısızca verilmiştir. Dışarıdan mal getirilmesine bir sınırlama konmadığ1 halde iç pazarda kıtlık doğurması veya düşmanın işine yarar düşüncesi ile birtakım malların (pamuk, demir, kurşun, hububat, deri, balmumu) ihracı zaman zaman yasak edilmiştir. Osmanlılar için Batı'dan özellikle gümüş ithali büyük önem taşırdı. $\mathrm{Bu}$ nedenle altın ve gümüş üzerinden gümrük alınmazd1 ${ }^{11}$. Fakat gümüş, Türkiye'den, altına göre daha yüksek paritesi olan Hindistan ve İran'a kaçmakta idi. Gümüş para darllğı, ekonomi ve devlet girişimlerini kısıtlayan önemli bir faktör olmuștur..."

Berkes’in (2013) de belirttiği üzere esasında merkantilist politikalar ile kapitülasyon politikası teorik açıdan birbirinin zıddıdır. Bununla birlikte dış ticaret ilişkisi kuran iki ülke açısından bakıldığında ise söz konusu politikaların birbirinin tamamlayıcısı olduğu görülmektedir. Öyle ki merkantilist politika izleyen bir ülke için en iyi ticaret, kapitülasyon politikası izleyen ülkeyle yapılanıdır. Bu ilişkide kapitülasyon politikası izleyen taraf, merkantilist politika izleyen taraf için "ideal bir ortak"tır. Kapitülasyon politikasında devlet savaş yapacağı bir devletle uğraşmak için karşıllŏgnda daha büyük bir kazanç sağlayacağı düşüncesiyle çok büyük miktarda harcama yaparken; savaş halinde bulunmadığı devletlere ise bu barış halini sürdürmek için çok büyük miktarda ekonomik kazançlar sağlar. Başka deyişle çifte zarara katlanır. Rasyonel bir değerlendirme yapıldığında bu durum çelişkilidir. Şöyle ki fazlasıyla müsrif bir tutumdur (Berkes, 2013, s. 189).

$\mathrm{Bu}$ durumda Osmanlı yöneticilerinin, Akdeniz dâhil Osmanlı ülkesinde ticarete hâkim olmaları pahasına Batı Avrupalılar'a ticari imtiyaz vermeleri nasıl açıklanabilir? Tanzimat Dönemi Osmanlı yazarlarının, kapitülasyonların zararlarının çok geç olarak anlaşılmaya başlandığı bir zamanda bile bunları siyasal kötülüğü olan bir lütuf saydıkları ve bu politikanın yol açtığı iktisadi yıkımı göremeyerek soruyu politik bir mazeret biçiminde cevaplandırdıkları kabul edilebilir (Berkes, 2013, s. 190). Başka deyişle Weberyan objektif rasyonalite yönünden Osmanlı insanının zihniyetinde dış ticaretin rasyonel iktisadi temellere dayalı bir açıklaması bulunmamaktadır. Konuya ilişkin olarak yukarıda belirttiğimiz Osmanlı zihniyet ilkeleri çerçevesinde kapitülasyonların Weberyan subjektif rasyonalite bağlamında bir uygulama olduğu kabul edilebiliri ${ }^{12}$.

Son olarak merkantilizm ve sonrası gelişmeler üzerine bazı açıklamalar yapılması uygun olacaktır. Buraya kadar anlatılanlar kapitalist zihniyetin sadece merkantilizmin temel motivasyon kaynağı olan “ülkeye değerli maden girişini artırması” düzeyiyle sınırlı kalmıştır. Oysa Avrupa deneyimi bize coğrafi keşiflerle birlikte Avrupalı devletlerin kendilerinde bulunmayan/üretilmeyen ham madde ve yarı mamullere meta ticareti yoluyla ulaşarak imalata yöneldiklerini ve bu sayede sermaye birikimini artırdıklarını

\footnotetext{
${ }^{11} \mathrm{Bu}$ durumun sebebi esasında o dönemde altın ve gümüșten yapılmış metal paraların kullanılmasıdır. Osmanlı yönetimi ülkeye değerli maden (altın ve gümüş) girişini teşvik edip bu madenlerin ülkeden çıkışlarını yasaklamak suretiyle ülkede para arzı kaynağının daralmamasını amaçlamışlardır (Küçükkalay, 2001, s. 107). Pamuk (2012, s. 18) ise iki sebep ileri sürmektedir. İlki, İslami geleneğe sahip Osmanlı yönetimi için egemenliğin en önemli simgelerinin sikke ve hutbe olmasıdır. İkincisi ise, Osmanlı yöneticilerinin bir yandan vergi toplamak, diğer yandan devlet personeline, tüccara ve diğer kesimlere ödeme yapmak için paraya ihtiyaç duymalarıdır. Bunun yanında paranın bolluğu ve tedavülü ile ticaretin ve iktisadi hayatın sağlığı ve canlılığı arasında güçlü bir ilişki bulunduğunun bilincinde olmuşlardır. Osmanlı Devleti uzun mesafe ticaret yolları üzerinde kurulmuş olup uzun mesafe ticaret devlet ve ekonomi için her zaman büyük önemde olmuştur. Uzun mesafe ticaret için de istikrarlı bir para düzeni büyük önem taşımıștur.

${ }^{12}$ Weberyan anlamda objektif rasyonalite ve subjektif rasyonalite kavramları için bk. Bozpinar (2018) ve Bozpinar (2020).
} 
göstermektedir. Bu durum kapitalist kazanç güdüsünün harekete geçmiş olduğu anlamını taşır ki Osmanlı zihniyeti ile Batı Avrupa zihniyetinin farklılı̆g13 Osmanlı Devleti'nin gerileme döneminden itibaren sermaye birikimi açısından ortaya çıkan yetersizliğin ve kapitülasyonların ülke ekonomisinde yol açtığı tahribatın temel belirleyicilerinden olmuştur ${ }^{14}$. Kapitülasyonlar, Avrupalı ülkeler ile Osmanlı Devleti arasında ticarete imkân ve kolaylık sağlamıştır. Batı Avrupa ülkelerinin izlediği merkantilist politika ile Osmanlı tarafinın izlediği "kendine özgü" ticaret politikası birbirini tamamlayıcı bir çift oluşturmuştur. Bu ilişkide merkantilist politika mamul mal ihracı ve ham madde ithali yoluyla dış ticaret fazlasınna dayanmasıyla sermaye birikimine imkân sağlamıştır. Konuyla ilgili olarak Küçükkalay (2001, s. 264)'dan şu aktarma uygun olacaktır:

“... Osmanlı ülkelerinde genellikle ham ipek, tiftik, pamuk ve meyan kökü gibi maddeler alıp; yünlü kumaşlar ve madeni eşya gibi mamul maddeler satan Levant Şirketi tüccarlarının büyük kârlan, İngiltere'deki sermaye birikimine ve İngiliz merkantilizminin gelişmesine önemli katkılarda bulundu..."

Merkantilizm'le başlayan kapitalist gelişme sürecindeki kapitülasyon sahibi Avrupa devletleri, Osmanlı ekonomisi üzerinde öldürücü darbeyi 1838 Balta Limanı Anlaşması'yla vurmuştur:

"Serbest ticaret anlaşması ile birlikte Osmanlı İmparatorluğu sınırları içindeki üreticiler, kendilerine göre daha gelişmiş ve hazırlıklı rakipleri karşısında daha önce karşılaşmadıkları bir rekabet ortamına girdiler. Geleneksel, düşük ölçekli ve daha çok el işçiliğine dayalı üretim yapan Osmanlı üreticileri, Büyük Britanya'nın sanayileşmiş modern üreticileriyle baş edemedi. Sonuçta, ortaya çıkan rekabet Osmanlı'da geleneksel üretim modeline son verdi. Birçok iş yeri (örneğin tekstil üreticileri) anlaşma yürürlüğe girdikten sonra kapandi. Özel şirketler modern imalathaneler kurabilmek için gerekli parasal ve beşerî kaynaklara da sahip değildi. Osmanlı'nın modern üretim modeline geçmesinin yolu böylelikle kapanmış oldu. Sanayi yerine ithalatçılık, temsilcilik gibi iş alanları gelişti.

Anlaşmadan sonra gümrük vergileri kalkarken ${ }^{15}$ iç taşımacılık vergilerinin devam etmesi, yerli üreticilerin uluslararası rakipleriyle baş etmesini daha zorlaştırdı..." (Yülek, 2019, s. 28).

\section{Sonuç}

Osmanlı Devleti'nde kapitülasyonlara ilişkin olarak literatürde genel olarak, başlarda işlevsel olduğu fakat ilerleyen dönemlerde işlevini yitirerek Osmanlı ekonomisine zararlı bir kurum niteliğine büründüğü kabul edilmektedir.

Yaklaşık 600 yıl bir imparatorluk niteliğiyle varlı̆̆ını korumuş bir devletin, kendi çöküşünde etkili olan böylesi önemli bir kuruma sahip olmasında iktisadi bir rasyonellik bulunup bulanmadı̆̆ına dair bilimsel merakın bir sonucu olarak bu çalışma ortaya çıkmıştır.

Bir derleme niteliğinde olan çalışmada, ulaşılabilen ikincil kaynaklarla sınırlı olmak üzere Osmanlı kapitülasyonlarının ortaya çıkışı iktisat tarihi perspektifinden incelenmiştir.

Elde edilen temel sonuç Osmanlı kapitülasyonlarının ortaya çıkışı hususunda Mehmet Genç’in ortaya koyduğu Osmanlı iktisadi dünya görüşünün temel ilkelerinin geçerli olduğudur. Başka deyişle dış ticaretin kolaylaştırılması için Osmanlı kapitülasyonlarının tesisi söz konusu temel ilkelere dayandırılmıştır. Böylece;

a) İaşe ilkesi doğrultusunda "ülke içinde malların mümkün olduğu kadar bol, kaliteli ve ucuz olmasını sağlamak yoluyla” halkın refahının artırılması amacı gerçekleştirilmiştir.

b) Fiskalizm ilkesi doğrultusunda, diş ticaret devlet için önemli bir gelir kaynağı olmuştur.

\footnotetext{
${ }^{13}$ Burada belirtilmesi gereken önemli bir husus XII. yüzyıldan XV. yüzyllın sonlarına kadar Avrupa yönetimlerinin iktisadi uygulamalarının da Osmanlı iktisadi zihniyet ilkelerinin temelinde gözetilen kaygılar tarafindan yönlendirildiğidir. Temel olarak bu kaygılar şehirlerin iaşesi merkezinde toplanmıştır. Osmanlı Devleti ile Avrupa'daki iktisadi uygulamalar arasındaki farklar daha sonları -XVI. ve XVII. yüzyıllarda- Avrupa'da merkantilist yaklaşımın ağılılık kazanmasıyla ortaya çıkmıştır (Pamuk, 2012, s. 13).

${ }^{14}$ Kapitülasyonların Osmanlı ekonomisi üzerindeki tahribatı Sanayi Devrimi sonrası dönemle sınırlıdır. Öncesi için mutlak bir tahribattan söz edilemez. Ayrıntılar için bk. Elibol (2005).

${ }^{15}$ Bu bilgi eksiktir. Balta Limanı Anlaşması'na göre; Osmanlı ülkesinde tüm tekeller yasaklanmıştır fakat İngiliz tüccarı Osmanlı ülkesi içinde $\% 3$ ithalat ve $\% 12$ ihracat vergisinin yanında diğer ithalatçıların yaptı̆g $\% 2$ oranında başka bir ödemeyi de yapacaktır (Issawi: 1980, s. 74-5).
} 
c) Gelenekçilik ilkesi doğrultusunda Osmanlı Devleti’nin tarih sahnesine çıktığı dönemden önce tesis edilmiş kapitülasyon kurumu, diş ticarete ilişkin kurulu düzeni bozmamak adına tanınmıştır.

Son olarak kapitalizm öncesi bir ekonomik yapıda olan Osmanlı Devleti'nde Weberyan subjektif rasyonalite çerçevesinde kapitülasyonların ortaya çıktığı kabul edilebilir.

\section{Extended Abstract}

Initially, the Ottoman capitulations were implemented as expected. However, their utility gradually diminished, and they became disruptive to the Ottoman economy in the XIXth century. The Ottoman state endured for approximately six hundred years; therefore, it is important to investigate its economic motives. This is a compilatory study. The establishment of the Ottoman capitulations has been handled from the perspective of economic history, limited to available secondary sources.

The capitulations, which seemed to have been granted as favors during periods of strength, gradually lost their function and became disruptive to the Ottoman economy in the XIXth century.

The capitulations date back to the pre-Ottoman period.

Although non-Muslims were named as antagonists in determining the legal status of foreigners in the state, this had practically no significance regarding capitulations. The origin of capitulations was not attributed to Islamic social formations, and foreigners were not seen as enemies according to Islamic law.

Although examples of capitulations existed prior to the XVIth century, the privileges that were first given to France in 1535 and then made indefinite after being renewed seven times formed the basis for the capitulations established in later periods.

Capitulations occurred in the Ottoman State due to certain reasons.

Firstly, capitulations existed in the pre-Ottoman period. When the Ottoman State was founded at the end of the XIIIth century, the practice of capitulations was alive and well. The Byzantine Empire gave certain privileges to various countries to maintain its domestic and foreign policy. Seljuk administrations also implemented similar practices. Therefore, with the conquest of those regions, the practice of capitulation was also applied to the Ottoman State. Secondly, Islamic jurisprudence maintains the institution of "amân," in which non-Muslims who professed "friendship and sincere goodwill" were given the necessary guarantee (amân) of secure residence, travel, and trade within the empire. Therefore, capitulations in the Ottoman State were recognized as a suitable form of public administration. Thirdly, capitulations aimed to establish political goodwill with European countries. According to Ottoman thought, capitulations meant gaining allies in the Christian world. Finally, economic motives for capitulation included the procurement of commodities unavailable in the state and the taxation of foreign trade. Thus, the Ottoman State benefitted from its location on the world's major trade routes (Silk Road and Spice Road). In fact, capitulations were likely meant to prevent the redirection of the Spice Road following the discovery of the Cape of Good Hope.

The aforementioned points support Mehmet Genç's theory of Ottoman economic thought regarding the establishment of the Ottoman capitulations. In line with the principle of provisionism, the welfare of the people was improved "by ensuring that the commodities were as plentiful, of high quality and cheap as possible". Within the framework of fiscalism, foreign trade was an important source of income for the state. In accordance with traditionalism, the foreign trade arrangement preceding the Ottoman State was recognized to avoid disruption of the established order. Finally, the establishment of the Ottoman capitulations was based on Weberian subjective rationality.

Keywords: Ottoman, capitulation, Mehmet Genç, mindset.

\section{Kaynakça}

Acartürk, E. \& Kılıç, R. (2011). Osmanlı Devleti'nde kapitülasyonların iktisadi ve siyasi perspektiften analizi, Hacettepe Üniversitesi İktisadi ve İdari Bilimler Fakültesi Dergisi, 29 (2), 1-21.

Akgündüz, A. (2011). İsâm ve Osmanlı Hukûku külliyâtı (cilt 1). İstanbul: Osmanlı Araştırmaları Vakfı.

Akgündüz, A. (2018). Osmanlı tarih ve bukuk ıstılâbları kâmûsu. İstanbul: Osmanlı Araştırmaları Vakf1.

Berkes, N. (2013). Türkiye iktisat taribi. İstanbul: Yap1 Kredi Yayınlar1. 
Bozpinar, C. (2018). Osmanl Devletinde iktisadi zihniyet ve sanayilesme sorunsali: Bursa ipek sektörü örneği. Yayımlanmamış doktora tezi, Hacettepe Üniversitesi Sosyal Bilimler Enstitüsü, Ankara.

Bozpinar, C. (2020). Weberyan subjektif rasyonalite: Osmanl iktisadi rihniyeti. Efil Journal, 3 (9), 126-45.

Demirkent, I. (2000). 1082-1302 ynllar arasinda Bizans-Venedik iliskilerine kisa bir bakıs. Tarih Dergisi, (36), 137-54.

Elibol, N. (2005). XVIII. yü̈ynl Osmanl dış ticaretiyle ilgili baz̧ değerlendirmeler. Eskişehir Osmangazi Üniversitesi Sosyal Bilimler Dergisi, 6 (1), 61-76.

Fayda, M. (2013). Zimmî. İçinde İslam ansiklopedisi (cilt 44, ss.428-34). Erișim https:/ /islamansiklopedisi.org.tr/zimmi\#1.

Genç, M. (2012). Osmanlı İmparatorluğu'nda devlet ve ekonomi (8. bask1). İstanbul: Ötüken Neşriyat.

Issawi, C. (1980). The Economic history of Turkey: 1800-1914. Chicago: The University of Chicago Press

Ínalcık, H. (2000). İmtiyâzât. İçinde İslam ansiklopedisi (cilt 22, ss.245-52). Erişim https://islamansiklopedisi.org.tr/imtiyazat\#2-osmanli-donemi.

İnalc1k, H. (2009a). Osmanl İmparatorlü̆u'nun ekonomik ve sosyal taribi: 1300-1600 (3. bask1). (Çev. H. Berktay). İstanbul: Eren Yayıncilik.

Inalc1k, H. (2009b). Devlet-i Aliyye Osmanlı Imparatorluğu üzẹine araştırmalar-I (30. bask1). İstanbul: Türkiye İş Bankası Kültür Yayınları.

Kapitülasyon. (t.y.). Türk Dil Kurumu Güncel Türkçe Sözlük. Erişim https:/ / sozluk.gov.tr/.

Kenanoğlu, M. M. (2013). Zimmî. İçinde İslam ansiklopedisi (cilt 44, ss.438-40). Erişim https://islamansiklopedisi.org.tr/zimmi\#3-osmanlilarda.

Kuran, T. (2018). Yollar ayrlırken: Ortadoğu'nun geri kalma sürecinde islam bukukunun rolü (2. bask1). (Çev. N. Elhüseyni). İstanbul: Yapı Kredi Yayınları.

Küçükkalay, A. M. (2001). Coğrafi keşifler ve ekonomiler: Avrupa ve Osmanl Devleti. Konya: Çizgi Kitabevi. Küçükömer, İ. (2012). Batıllaşma \& Düzenin yabancılaşması (3. baskı). İstanbul: Profil Yayınc1lı.

Kütükoğlu, M. S. (1999). Ahidnâmeler ve ticaret muâhedeleri. İçinde G. Eren (Ed.), Osmanlı (cilt III, ss.329-41). Ankara: Yeni Türkiye Yayınları.

Özel, A. (1984). İslâm bukukunda ülke kavram: Dâru'l islâm-Dâru'l harb. İstanbul: Marifet Yayınları.

Özel, A. (1997). Harbî. İçinde İslam ansiklopedisi (cilt 16, ss.112-4). Erişim https://islamansiklopedisi.org.tr/harbi--gayr-i-muslim.

Pamir, A. (2002). Kapitülasyon kavram ve Osmanl Devleti’ne etkileri. Ankara Üniversitesi Hukuk Fakültesi Dergisi, 51 (2), 79-119.

Pamuk, Ş. (2012). Osmanl Imparatorluğu'nda paranın taribi (5. bask1). İstanbul: Tarih Vakfi Yurt Yayınları.

Sousa, N. (1933). The Capitulatory Regime of Turkey. Baltimore: The Johns Hopkins Press.

Tabakoğlu, A. (1998). Türkiye iktisat tarihi (4. bask1). İstanbul: Dergâh Yayınları.

Valensi, L. (2015). Avrupa'da Müslümanlar: 16.-18. yüzynllar. (Çev. A. Tümertekin). İstanbul: Türkiye İş Bankası Kültür Yayınları.

Yaman, A. (2013). Zimmî. İçinde İslam ansiklopedisi (cilt 44, ss. 434-8). Erişim https://islamansiklopedisi.org.tr/zimmi\#2-fikih.

Yülek, M. (2019). Uluslarn yükselisi: Imalat, ticaret, sanayi politikasi ve ekonomike kalkernma. İstanbul: Kronik Kitap. 